\title{
Aspen Parkland Pasture Altered by Richardson's Ground Squirrel (Urocitellus richardsonii Sabine) Activity: The Good, the Bad, and the Not So Ugly?
}

\author{
LeVi J. NeWEdiuK ${ }^{1}$, Isobel Waters ${ }^{1}$, and JAMES F. HARE ${ }^{1,2}$ \\ ${ }^{1}$ Department of Biological Sciences, University of Manitoba, Winnipeg, Manitoba R3T 2N2 Canada \\ ${ }^{2}$ Corresponding author: james.hare@ad.umanitoba.ca
}

Newediuk, Levi J., Isobel Waters, and James F. Hare. 2015. Aspen parkland pasture altered by Richardson's Ground Squirrel (Urocitellus richardsonii Sabine) activity: the good, the bad, and the not so ugly? Canadian Field-Naturalist 129(4): $331-341$.

\begin{abstract}
Although Richardson's Ground Squirrels (Urocitellus richardsonii) are considered pests throughout their North American range, their impact on forage in Canadian aspen parkland has not been explored. We investigated the effect of Richardson's Ground Squirrel density on forage quality and plant community composition in an intensely grazed cattle pasture in the aspen parkland region of Manitoba, Canada. We detected no significant differences in forage protein content or legume, grass, and litter biomass among ground squirrel density levels. However, ground squirrel density did influence the abundance of invasive and forage plant species; greater squirrel density reduced the prevalence of Smooth Brome (Bromus inermis Leysser) and Red Clover (Trifolium pratense L.) and increased the abundance of Quackgrass (Elymus repens (L.) Gould) and Black Medick (Medicago lupulina L.). Plant community diversity also increased with ground squirrel density. There were no differences in soil bulk density or ammonia content among squirrel density levels; however, soil nitrate content was highest at low ground squirrel density. Changes in available soil nitrogen and relative abundances of forage species on this pasture may affect cattle diet by altering both the availability and quality of forage. Our findings highlight the need for further investigation of the role of Richardson's Ground Squirrel on rangeland in the aspen parkland region to ascertain the generality of the effects documented in our study. Until such effects and their implications for cattle production are understood, land managers should refrain from exterminating colonies of Richardson's Ground Squirrel.
\end{abstract}

Key Words: Richardson's Ground Squirrel; Urocitellus richardsonii; aspen parkland; intermediate disturbance; community structure; rangeland; cattle; grazing

\section{Introduction}

In North America, ground squirrels (tribe Marmotini [Sciuridae]) contribute significantly to forage crop and livestock losses. In Montana, alfalfa crop losses range from $24 \%$ to $31 \%$ in areas of high ground squirrel density, resulting in annual financial losses as high as $\$ 7$ million state-wide (Johnson-Nistler et al. 2005). Similarly, in California, ground squirrels reduce alfalfa crop yield by $39-48 \%$, imposing an annual cost of $\$ 233-$ $335 /$ ha (Whisson et al. 1999). In a United States-wide survey, rodents, including ground squirrels, accounted for over $15 \%$ of wildlife-caused losses reported by livestock producers (Wywialowski 1994), either via competition for forage (Howard et al. 1959) or perceived animal injury resulting from uneven ground caused by burrowing (Jameson 1973; Calder 2003). Given the economic importance of agricultural production, several studies have explored the feasibility of ground squirrel management methods, such as poisoning and shooting, in terms of cost effectiveness and effects on crop and animal yield (Whisson et al. 1999; Johnson-Nistler et al. 2005).

Despite evidence suggesting adverse effects of ground squirrels on agricultural land, the universal acceptance of Richardson's Ground Squirrels (Urocitellus richardsonii) as pests remains controversial. Although few scientific studies have been conducted that describe the effects of ground squirrels on pastureland, they have been regarded as major agricultural pests in the aspen parkland and mixed prairie regions of Canada since the late 19th century. Calder (2003) suggests that this perception stems from the traditional view that the production potential of agricultural land is compromised by its use by native wildlife. The foraging activities of prairie dogs (Cynomys spp.), which are of similar concern to agricultural producers but occur south of the aspen parkland, reportedly reduce forage biomass (Winter et al. 2002), increase the nitrogen content of forage through compensatory growth (Coppock et al. 1983), and promote the presence of short- to mid-height perennial grasses (Winter et al. 2002) and exotic species (Fahnestock and Detling 2002). The effect of grounddwelling rodents on the distribution of plant species may be particularly important to livestock producers, where they influence the distribution of toxic and nutritionally important forage species. Despite the paucity of empirical evidence for either improvement or degradation of agricultural land quality by ground-dwelling rodents in Canadian agricultural areas, extermination of ground squirrels is both accepted and encouraged (Calder 2003).

An empirical understanding of ground squirrel impacts on pastureland is critical for the development of economical and environmentally sound pasture management practices on the Canadian prairies. The com- 
plete removal of ground squirrel colonies may have adverse effects on the pastureland community by limiting nitrogen input and disrupting predator-prey relationships. Elimination of ground squirrels from pastureland may also affect pasture quality by limiting soil aeration, which may reduce soil compaction caused by cattle trampling (Houlbrooke et al. 2009), or by reducing water infiltration to deeper layers of the soil profile where burrows were once present (Laundre 1993). Finally, reducing the density of ground squirrels on pastureland may compromise the persistence of such species as the endangered Burrowing Owl (Athene cunicularia), which relies on abandoned ground squirrel burrows for nesting habitat (Poulin et al. 2005).

Given the controversy surrounding Richardson's Ground Squirrels on pastureland, we conducted a preliminary study to assess changes in forage quality on a pasture in the aspen parkland region of Manitoba, Canada. We compared forage and soil characteristics across three ground squirrel foraging densities within a single pasture, so as to unambiguously ascribe any treatment effect to ground squirrel density and not confound that assessment with myriad biotic and abiotic factors that vary considerably among pastures. We hypothesized that soil nitrogen and crude protein content of forage would increase with ground squirrel foraging density and that available forage biomass, moisture, and bulk density would decrease with foraging density. We also hypothesized that plant species diversity would peak at intermediate density (as predicted by the intermediate disturbance hypothesis [Grime 1973]), and that plant species assemblages would differ across foraging densities.

\section{Study Area}

The study site was a cultivated 7.4-ha pasture located just east of Westbourne, Manitoba $\left(50^{\circ} 10^{\prime} 4^{\prime \prime} \mathrm{N}\right.$, $\left.98^{\circ} 30^{\prime} 10^{\prime \prime} \mathrm{W}\right)$. The pasture has been grazed intensively since 1970 , with cattle stocking rate during our study at five head/ha. Because of that relatively high stocking rate, combined with the apparent homogeneity of the pasture, we were confident that all areas of the pasture had an equal probability of being grazed by cattle. Indeed, the topography of the site is generally flat, without temporary or permanent wetlands, and it lacks any large-scale changes in plant community structure or any obvious disparities in cattle-grazing activity. The soil type is clayey lacustrine (black chernozems), with consistent texture throughout the pasture. Forage grasses with the greatest percentage cover include introduced species, such as Smooth Brome (Bromus inermis Leysser), Quackgrass (Elymus repens (L.)), and native Kentucky Bluegrass (Poa pratensis L.). Black Medick (Medicago lupulina L.) and Red Clover (Trifolium pratense L.) are also common (Table 1). These and other legumes have been seeded in the region to enhance the feed value of pastures (McCartney 1993). All species identified pasture-wide are listed in Table 1 according to abundance.

TABLE 1. Pasture-wide forage species, in order of descending abundance in an aspen parkland pasture in Manitoba.

\begin{tabular}{ll}
\hline \hline Rank & Species \\
\hline 1 & Kentucky Bluegrass (Poa pratensis L.) \\
2 & Red Clover (Trifolium pratense L.) \\
3 & Quackgrass (Elymus repens (L.) Gould) \\
4 & Smooth Brome (Bromus inermis Leysser) \\
5 & Black Medick (Medicago lupulina L.) \\
6 & Common Dandelion (Taraxacum officinale F. H. Wiggers) \\
7 & Canada Thistle (Cirsium arvense (L.) Scopoli) \\
8 & Garden Bird's-foot Trefoil (Lotus corniculatus L.) \\
9 & Flodman's Thistle (Cirsium flodmanii (Rydberg) Arthur) \\
10 & Common Plantain (Plantago major L.) \\
11 & Common Timothy (Phleum pratense L.) \\
12 & Unidentified forb \\
13 & Common Silverweed (Potentilla anserina L.) \\
14 & Unidentified forb \\
15 & Unidentified forb \\
16 & Unidentified forb \\
17 & Northern Fairy-candelabra (Androsace septentrionalis L.) \\
18 & Unidentified forb \\
19 & Unidentified forb \\
20 & Unidentified forb \\
\hline \hline
\end{tabular}

\section{Methods}

\section{Estimating Ground Squirrel Density}

Three ground squirrel foraging densities were determined by subdividing the site based on observations of aboveground squirrel activity and burrow use. Burrows provide refuge for squirrels disturbed during foraging
(Batzli and Sobaski 1980; Davis 1984) and are often surveyed to estimate local ground squirrel abundance (Proulx et al. 2012). Because Richardson's Ground Squirrels cluster in areas with dense concentrations of active burrows, we assumed that foraging was most intense where burrows were most frequently used. We 
made observations on three dates: 3,9 , and 12 June 2010 , starting at least 2 weeks after juvenile emergence had ended so that males and females of all age classes were active above ground. Sampling was conducted over a 2 -h period between 0900 and 1500 central daylight time, under conditions suitable for aboveground activity by ground squirrels, on days without precipitation or strong wind, and with temperatures between $10^{\circ} \mathrm{C}$ and $27^{\circ} \mathrm{C}$. Three observers marked squirrel sightings at burrow entrances in an observation area of 12 ha each using scan sampling (Martin and Bateson 1986). Because we were concerned only with total foraging activity, rather than activity of individual squirrels, sightings were recorded regardless of whether the individual had already been sampled. Observers rotated through different areas of the pasture to avoid observer bias. We recorded locations of burrow entrances using a WAAS (wide area augmentation system)-corrected Garmin GPS 72 with accuracy of $\pm 5 \mathrm{~m}$ (Garmin Ltd., Olathe, Kansas, USA).

We used the locations of burrow entrances to create a density map of ground squirrel foraging intensity in Arc GIS using the animal movement extension (ESRI, Redlands, California, USA). We defined 5-m-radius buffers around each sighting location to account for squirrel foraging distance from the burrow entrance, given that core areas used by juvenile ground squirrels for burrowing and feeding are approximately $50 \mathrm{~m}^{2}$ at 5-6 weeks of age and, typically, do not exceed approximately $250 \mathrm{~m}^{2}$ within the first season preceding hibernation (Michener 1981). As buffers approximated foraging distances from the burrow entrance, foraging was considered to be most frequent where buffers overlapped. We designated areas in which at least two buffer layers overlapped as high-foraging-density areas and those with a single buffer layer as intermediate-density areas. We assumed that squirrels had been locally extirpated from areas with no sightings over the 3 sampling days, attributing the absence of squirrels in those areas to intensive, and yet patchily distributed removal by shooting, which the pasture's owners reported to have occurred in the summer of 2009. However, as it was impossible to conclude definitively that squirrels did not at least occasionally use those areas, we conservatively designated them as low-density areas (Figure 1).

Within each density level, we generated 20 random sample points, which we located on 22 June 2010, subject to the restriction that those points on site contained both vegetation and soil and were undisturbed except for grazing. If a generated sample point did not contain vegetation representative of the pasture in general (i.e., if it was located on a cow pat or mound, or contained a burrow entrance), a new random sample point was generated. To independently verify high-, intermediate-, and low-density areas, we counted the number of active and inactive nest and escape burrow entrances in nonoverlapping $20 \times 20 \mathrm{~m}$ quadrats surrounding the centre of each sample point on 29 June 2010. Within each quadrat, we recorded the number of active burrow entrances, which we identified to be those with visible recent excavation. We subcategorized active burrow entrances into escape entrances, which exceeded the girth of an adult ground squirrel, and nest entrances, which equaled the girth of an adult ground squirrel. Burrow entrances that were closed or overgrown with vegetation and had no evidence of recent excavation were considered to be inactive. Although each sample point was marked with a metal spike and flagging tape, several of them became impossible to locate over the course of the season despite attempts using GPS and an MD3005 metal detector (Famous Trails, Anaheim, California, USA). For this reason, sample size was reduced for a number of measurements.

\section{Vegetation Sampling}

From 22 to 24 June 2010, we clipped all aboveground portions of plants at ground level in two $25 \mathrm{~cm}$ $\times 25 \mathrm{~cm}$ quadrats per sample point and placed the harvested vegetation and litter in either paper bags for dry biomass determination $(n=20$ per density level) or sealable plastic bags for crude protein determination ( $n=10$ per density level). To prevent overlap with vegetation surveys, we placed the quadrats northwest (biomass) and southeast (protein) of the sample point, with the corner of each quadrat touching the marker. We considered shoots to be in the quadrats if they were rooted on or within the edge of the quadrat. Before harvest, we estimated average vegetation height in each dry biomass quadrat using the drop disc method (Stewart et al. 2001). A $30 \mathrm{~cm}$-diameter corrugated plastic disc weighing $54.29 \mathrm{~g}$ and with the centre cut out to fit over a metre stick was dropped from a height of $50 \mathrm{~cm}$ into the centre of the quadrat. When the disc came to rest, we recorded its height on the metre stick (to the nearest $\mathrm{mm})$. The width of the plastic $(4 \mathrm{~mm})$ was subtracted from all height measurements.

The vegetation harvested for dry biomass determination was dried in a $65^{\circ} \mathrm{C}$ oven to a constant weight (40 h), and the average weight of a dried paper bag (obtained from a sample of 20 paper bags) was subtracted from this to obtain the total vegetation weight per quadrat. Following drying and weighing, we sorted vegetation into three categories: grasses, legumes, and non-leguminous forbs. We placed the sorted vegetation in new paper bags and dried it at $65^{\circ} \mathrm{C}$ to a constant weight (additional $5 \mathrm{~h}$ per bag), to control for moisture that may have been transferred to the vegetation from the air or hands during the sorting process. Sorted vegetation was weighed again to obtain the dry mass of grasses, legumes, and non-leguminous forbs.

Vegetation harvested for protein determination was transported to the laboratory on ice. To reduce variation in samples due to differences in species composition among quadrats, we used only tissue of two of the most common species, Medicago lupulina and Poa pratensis, for crude protein analysis. We weighed out $8 \mathrm{~g}$ of leaf tissue from each species for each harvested quadrat 


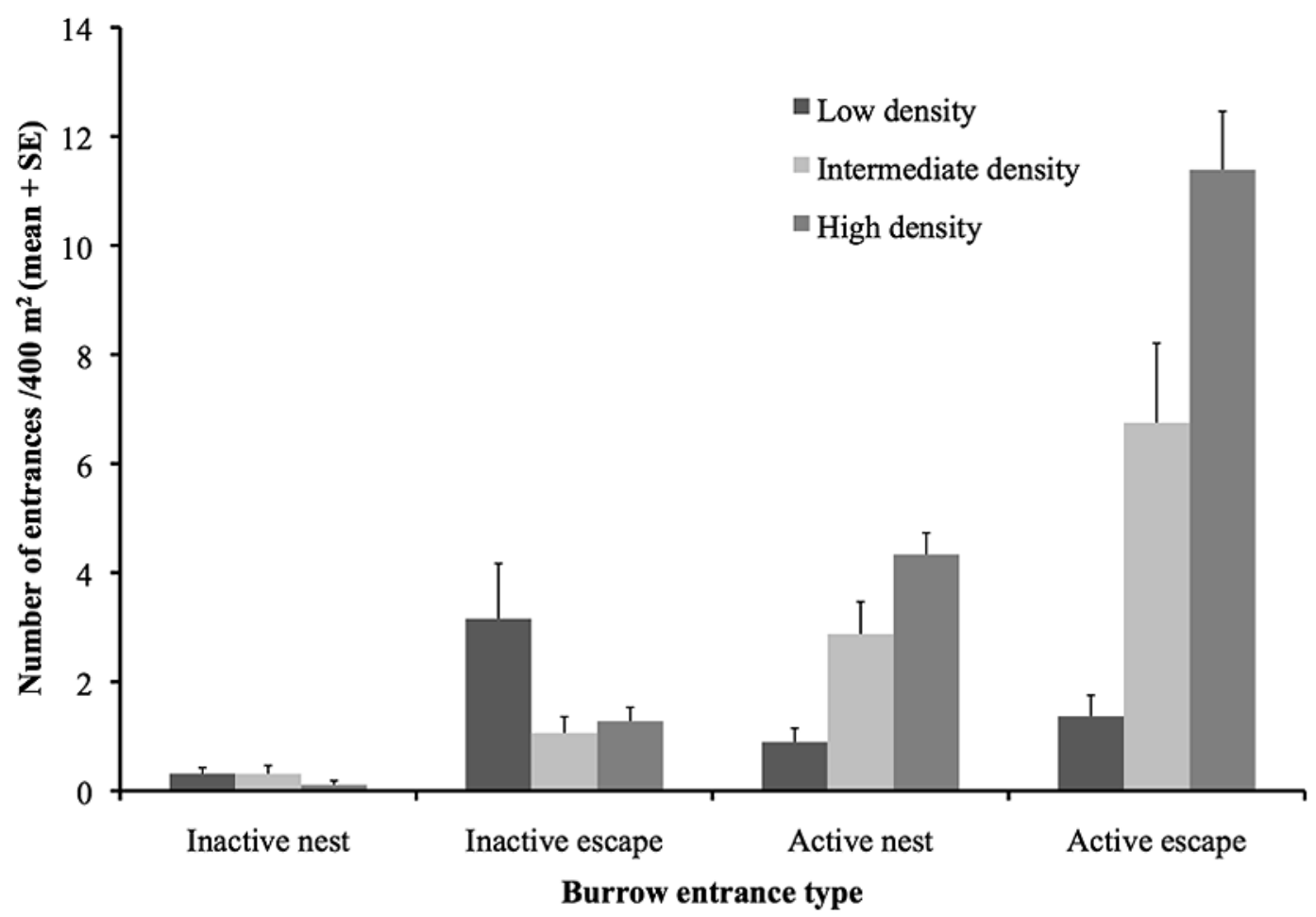

FIgURE 1. Number of burrow entrances in 400- $\mathrm{m}^{2}$ plots in 19 low-, 20 intermediate-, and 18 high-density Richardson's Ground Squirrel (Urocitellus richardsonii Sabine) areas in Manitoba. Nest burrow entrances equaled the girth of an adult ground squirrel. Escape burrows were defined as all of those that exceeded the girth of an adult ground squirrel. Active burrows had signs of recent excavation. Burrows with entrances closed or overgrown with vegetation and with no evidence of recent excavation were considered to be inactive.

and wrapped it in aluminium foil. We then flash froze the tissue by submerging the foil packets in liquid nitrogen for $20 \mathrm{~s}$, and immediately placed them into a freezer at $-80^{\circ} \mathrm{C}$ for subsequent protein analysis (see below). Because harvests were performed mid-season, forage nutrition content was likely at a moderate level (Wallace et al. 1972).

\section{Crude Plant Protein Determination}

We processed and prepared the flash-frozen leaf tissue of Medicago lupulina and Poa pratensis for protein determination by grinding tissue samples in liquid nitrogen. We extracted the protein using $25 \mathrm{~mL}$ of cold phosphate buffer $(\mathrm{pH}$ 7.0) following the methods of Jones et al. (1989). A solution of $1 \mathrm{mM}$ EDTA, $1 \%$ polyvinylpyrrolidone, and $1 \mathrm{mM}$ ascorbate was added to the buffer as a protein protectant (Zhao et al. 2008). We allowed extraction to proceed on ice for 20 minutes, then centrifuged the homogenate at $4^{\circ} \mathrm{C}$ for 20 minutes at $15000 \mathrm{~g}$. We measured protein content in $15 \mathrm{~mL}$ of the supernatant using the Bradford (1976) method. A bovine serum albumin standard was used to create a standard curve after each preparation of the phosphate buffer.

\section{Vegetation Surveys}

On 29 and 30 June 2010, we estimated plant species cover in $1 \mathrm{~m} \times 1 \mathrm{~m}$ quadrats placed at the northeast corner of each sample point. At this point in the season, forbs and grasses should have amassed 30\% and 50\% of their maximum seasonal organic matter, respectively (Wallace et al. 1972). We estimated the percentage cover of each species to the nearest $1 \%$, except when species were present in trace amounts. These species were given values of either $0.7 \%$ (one moderate-sized plant or two to three small plants) or $0.1 \%$ (one small plant). We considered individual plants to be in the quadrat if they were rooted on or inside the quadrat edge. The same two observers estimated percentage cover in all quadrats to avoid sampling bias and ensure consistency of estimates among quadrats; the two independent estimates of each species were averaged.

\section{Soil Moisture}

We measured soil moisture at each sample point on 29 June 2010 ( $48 \mathrm{~h}$ since rain) using a theta probe (Thermo Fisher Scientific Inc., Waltham, Massachusetts, USA). Although moisture sampling on multiple dates would have given a more meaningful estimate 
of overall moisture, few days in the 2010 season would have provided accurate moisture estimates because of frequent rainfall, as soil in this region remains saturated for up to 5 days following rain. Measurements were taken $15 \mathrm{~cm}$ to the northwest, northeast, southwest, and southeast of each sample point for a total of four readings; these were averaged to obtain a single moisture value for each sample point.

\section{Soil Bulk Density}

We obtained soil for bulk density determination by cutting out soil cores $5 \mathrm{~cm}$ in diameter to a depth of $10 \mathrm{~cm}$ about $30 \mathrm{~cm}$ northeast of the sample points and filling the holes with a known volume of sand measured in a $100-\mathrm{mL}$ graduated cylinder to determine volume. In the laboratory, we dried the cores at $105^{\circ} \mathrm{C}$ for $24 \mathrm{~h}$. We calculated bulk density by determining weight/volume for each soil core.

\section{Inorganic Nitrogen Analysis}

On 29 and 30 July 2010, we used a $20-\mathrm{cm}$ auger to obtain a single soil core about $30 \mathrm{~cm}$ southwest of each of the 44 sample points ( 14 high density, 15 low density, and 15 intermediate density). We air dried and ground the cores until the soil passed through a 2-mm sieve. We then weighed out $100 \mathrm{~g}$ of soil for nitrate analysis. Each $5.0 \mathrm{~g}$ of air-dried soil was extracted with $25 \mathrm{~mL}$ of $2 \mathrm{M} \mathrm{KCl}$ solution and shaken on a reciprocating shaker for 30 minutes at 150 excursions per minute. The resulting extract was then centrifuged for $90 \mathrm{~min}-$ utes at $3100 \mathrm{rpm}$. Nitrate/nitrite and ammonia concentrations in the resulting supernatant were determined using the cadmium reduction method (Clesceri et al. 1998).

\section{Data Analysis}

Although our study was conducted in a single pasture and, thus, represents a single replicate within the aspen parkland region as a whole, each sample point was treated as a separate sample for analysis of the effects of ground squirrel density on the pasture. Differences in burrow entrance density $(n=16)$ and vegetation and soil characteristics - including plant height $(n=18)$, dry biomass $(n=18)$, average percentage cover per species $(n=18)$, and crude protein $(n=8)$, as well as soil nitrate/nitrite $(n=14)$, ammonia $(n=14)$, bulk density $(n=14)$, and moisture $(n=18)$ - among the three squirrel density levels (high, intermediate, and low) were analyzed using one-way analysis of variance in Data Desk (Data Description, Inc., Ithaca, New York, USA). Soil nitrate data were log transformed before analysis. All results were considered significant where $P \leq 0.05$ because effect sizes could not be estimated before performing the analyses (Mudge et al. 2012).

We analyzed plant community data using multiple discriminant analysis (MDA) in Syn-Tax 5.1 (Exeter Software, Setauket, New York, USA) to evaluate differences in species composition among high, intermediate, and low ground squirrel density areas. MDA is a multivariate technique for significance testing among individuals that have been defined as belonging to $a$ priori groups (Brook and Kenkel 2002). This makes it an ideal method for exploring differences in the plant community in areas with different ground squirrel densities. The analysis compared species composition for each individual (quadrat) by maximizing within-group variation in species composition along $p$ axes corresponding to the number of principal components analysis (PCA) axes used as input in the MDA eigenanalysis. PCA axes were used as input to reduce the number of variables in the MDA analysis. We evaluated the significance of the MDA axes using Wilke's lambda, which was considered significant where $P \leq 0.05$.

We also compared diversity among ground squirrel density levels using Simpson's index:

$$
\text { [1] } D=\frac{\sum n(n-1)}{N(N-1)}
$$

where $n$ is the abundance of a species, and $N$ is the total abundance of all species. We selected this index because Simpson's index weights rare species less heavily than common species (Simpson 1949). Our study was concerned with major shifts in the plant community caused by ground squirrel activity and, therefore, rare species (those accounting for $<1 \%$ cover) were not considered significant to the questions at hand. Evenness among density levels was calculated using Kvålseth's (1991) equation:

$$
\text { [2] } E_{\alpha}=N_{\alpha} / N_{\alpha-1}
$$

where $N_{\alpha}=\left(\sum p_{i}{ }^{\alpha}\right)^{1 /(1-\alpha)}-1=s_{\alpha}-1$

is the number of defined species, and $\alpha$ is a parameter with a real number value. Whittaker plots comparing log percentage cover of species in order of decreasing abundance were used to compare evenness and diversity among squirrel density levels (Whittaker 1972).

\section{Results}

\section{Ground Squirrel Density}

Although the number of inactive burrow entrances did not differ significantly among Richardson's Ground Squirrel density levels, the number of active escape and nest burrow entrances increased significantly from low- to high-density areas (Figure $1 ; F_{2,52}=26.18, P$ $<0.0001$ ). Variation in the number of active nest burrow entrances within each quadrat ( $0-8$ entrances) was not as broad, however, as that for active escape burrows (0-21 entrances).

\section{Plant Community}

MDA revealed a transition in common grass and legume species from high to low ground squirrel foraging density. Separation of the three ground squirrel density groups was maximum along the first MDA axis $(\Lambda=0.59, P<0.001)$. In other words, the $a$ priori groups (foraging densities) of sample points were distinct from one another along the first axis in terms of plant species composition. PCA biplot scores of plant species superimposed on the MDA ordination revealed 
that percentage cover of Elymus repens and Medicago lupulina increased with increasing ground squirrel density. In contrast, Bromus inermis and Trifolium pratense percentage covers were greatest at lower squirrel densities (Figure 2). Medicago lupulina and Elymus repens differed most in magnitude among ground squirrel density levels $\left(F_{2,54}=4.75, P<0.05 ; F_{2,54}=6.20, P<0.01\right)$, while Bromus inermis and Trifolium pratense differed less among density levels, but the difference was still significant $\left(F_{2,54}=3.73, P<0.05 ; F_{2,54}=4.85, P<0.05\right.$; Table 2). Percentage cover of all legumes in low-den- sity quadrats tended to be higher than in either high- or intermediate-density quadrats, although this difference was not statistically significant $\left(F_{2,54}=1.62, P>0.20\right.$; Table 2).

Plant species diversity, as measured by Simpson's index $(D)$ (with Kvålseth's evenness $(E)$ ), was higher in plots with high ground squirrel density $(D=0.73$, $\left.E_{21}=0.09\right)$ than in plots where ground squirrel density was low or intermediate $\left(D=0.69, E_{21}=0.13 ; D=0.68\right.$, $E_{21}=0.11$ respectively). In Whittaker plots of log percentage cover of species versus rank abundance (ordi-

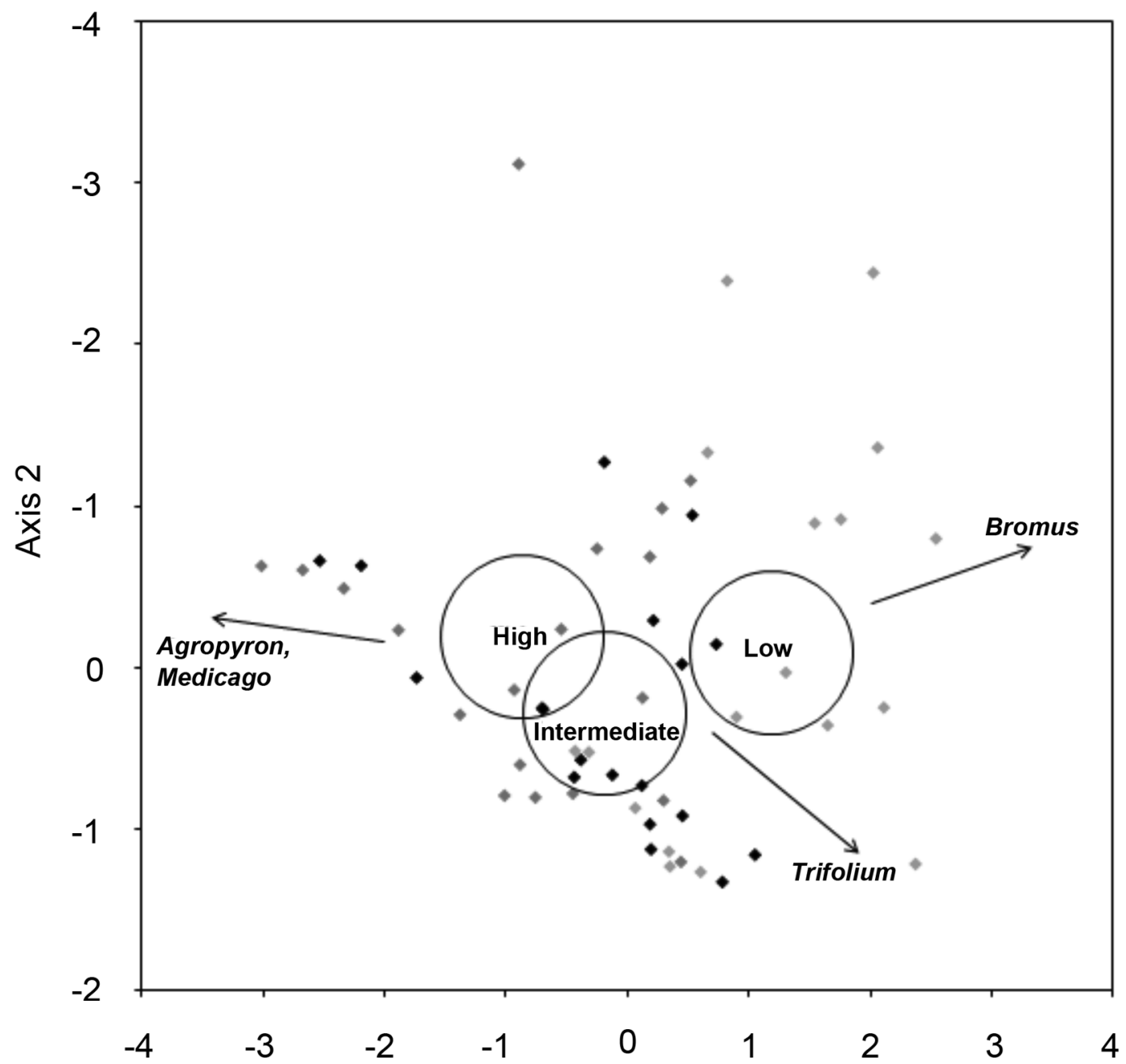

Axis 1

FIGURE 2. Multiple discriminant analysis ordination of principal components analysis (PCA) axes comparing plant species composition in quadrats (individuals) in 38 low-density, 38 intermediate-density, and 38 high-density Richardson's Ground Squirrel (Urocitellus richardsonii Sabine) areas in Manitoba. Circles represent 95\% confidence ellipses for groups. Arrows represent biplot scores of species on PCA axes for Bromus inermis, Elymus repens, Medicago lupulina, and Trifolium pratense. Axis 1 is statistically significant $(\Lambda=0.59, P<0.001)$. 
TABLE 2. Forb, legume, and grass cover (mean \pm standard deviation) in areas of high, intermediate, and low density of Richardson's Ground Squirrel (Urocitellus richardsonii Sabine) and pasture-wide in an aspen parkland pasture in Manitoba.

\begin{tabular}{|c|c|c|c|c|}
\hline & \multicolumn{4}{|c|}{ Squirrel density areas } \\
\hline & $\begin{array}{c}\text { Low } \\
(n=19)\end{array}$ & $\begin{array}{l}\text { Intermediate } \\
(n=20)\end{array}$ & $\begin{array}{c}\text { High } \\
(n=18)\end{array}$ & Pasture-wide \\
\hline \multicolumn{5}{|l|}{ Forbs } \\
\hline Medicago lupulina* & $3.8 \pm 0.7 \mathrm{a}$ & $8.4 \pm 2.3 \mathrm{ab}$ & $11.3 \pm 1.8 b$ & $7.8 \pm 1.1$ \\
\hline Trifolium pratense* & $31.2 \pm 5.3 \mathrm{a}$ & $18.2 \pm 3.5 b$ & $14.3 \pm 2.8 b$ & $21.2 \pm 2.5$ \\
\hline Cirsium arvense & $0.5 \pm 0.4$ & $2.5 \pm 1.8$ & $1.1 \pm 0.6$ & $1.1 \pm 0.6$ \\
\hline Lotus corniculatus & $0.9 \pm 0.5$ & $2.0 \pm 1.0$ & 0.0 & $1.0 \pm 0.4$ \\
\hline Taraxacum officinale & $2.3 \pm 0.7$ & $1.8 \pm 0.6$ & $0.1 \pm 0.1$ & $1.4 \pm 0.3$ \\
\hline Other forbs $\dagger$ & $0.1 \pm 0.0$ & $0.2 \pm 0.1$ & $0.2 \pm 0.1$ & $0.2 \pm 0.1$ \\
\hline Total forbs & $2.5 \pm 0.6$ & $2.2 \pm 0.4$ & $1.8 \pm 0.3$ & $2.1 \pm 0.3$ \\
\hline Total legumes & $35.9 \pm 5.4$ & $28.7 \pm 3.5$ & $25.6 \pm 3.1$ & $10.0 \pm 1.1$ \\
\hline \multicolumn{5}{|l|}{ Grasses } \\
\hline Bromus inermis* & $16.2 \pm 5.4 \mathrm{a}$ & $3.3 \pm 1.6 \mathrm{~b}$ & $6.7 \pm 3.2 \mathrm{a}$ & $8.8 \pm 2.3$ \\
\hline Elymus repens* & $7.3 \pm 1.9 \mathrm{a}$ & $16.6 \pm 3.4 \mathrm{~b}$ & $26.4 \pm 5.4 b$ & $16.8 \pm 2.4$ \\
\hline Poa pratensis & $65.7 \pm 4.0$ & $70.4 \pm 3.9$ & $55.8 \pm 6.8$ & $64.2 \pm 3.0$ \\
\hline Phleum pratense & $0.1 \pm 0.1$ & $0.7 \pm 0.5$ & $0.6 \pm 0.4$ & $0.5 \pm 0.2$ \\
\hline Total grasses $\S$ & $89.3 \pm 7.2$ & $93.1 \pm 4.7$ & $87.8 \pm 4.5$ & $22.6 \pm 2.0$ \\
\hline
\end{tabular}

*Different letters indicate significant differences among density levels $(P<0.05)$.

$\dagger$ Includes species with average percentage cover below 0.5\%: Cirsium floodmanii, Plantago major, Phleum pratense,

Potentilla anserina, Androsace septentrionales, and seven unidentified species.

Includes Medicago lupulina, Lotus corniculatus, and Trifolium pratense.

$\S$ Includes the four species listed in the table.

nal list of species from most to least abundant), lowdensity areas tended to have fewer species, with a few contributing greatly to plant abundance and others contributing very little (Figure 3). Low squirrel density areas had the fewest number of species and the most variation in abundance among those species (Figure 3), appearing as a geometric series (Whitaker 1972). The high and intermediate squirrel density areas were typified by lognormal distributions, a greater number of species overall, and more even distribution of each of those species throughout the area (Figure 3).

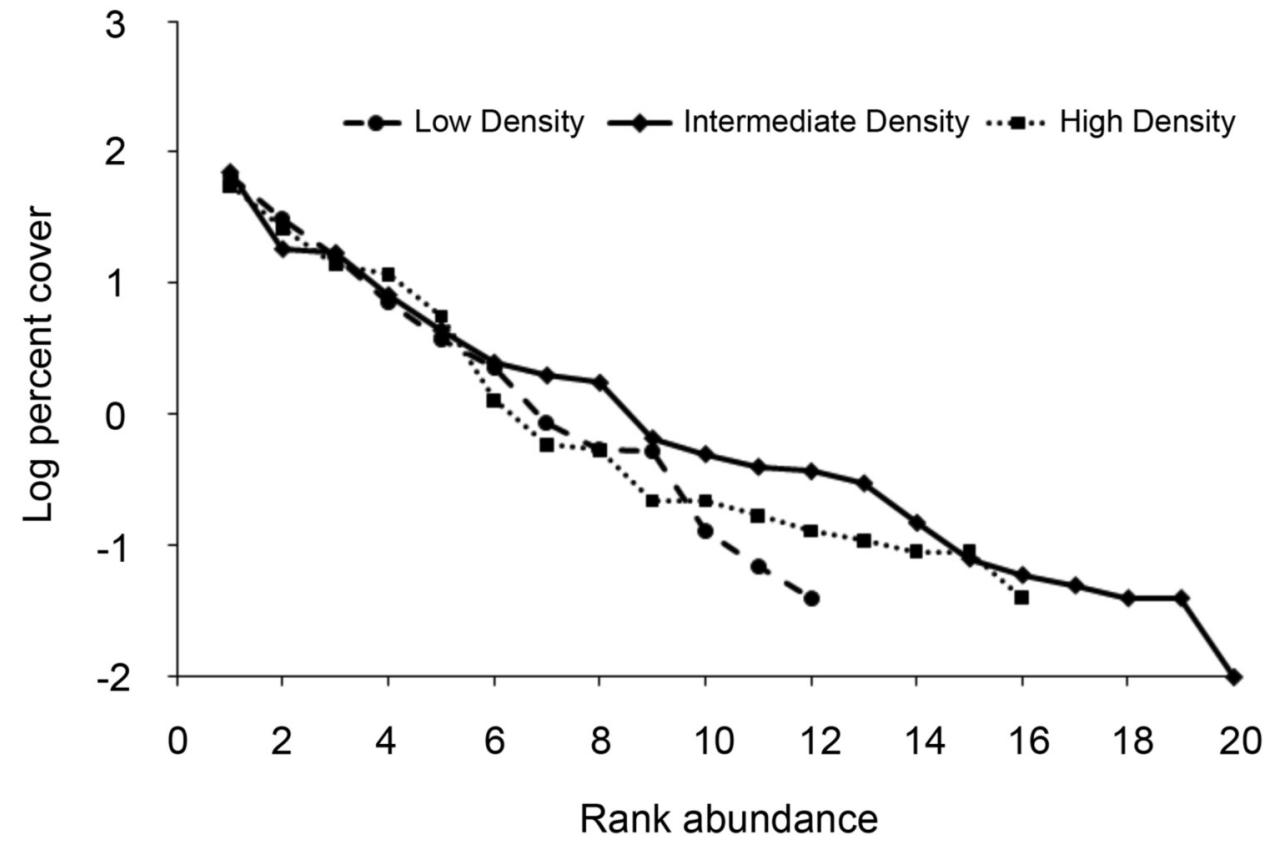

FIGURE 3. Whittaker plot showing differences in log percentage cover of plant species in decreasing order of abundance for 12 low-density, 16 intermediate-density, and 20 high-density Richardson's Ground Squirrel (Urocitellus richardsonii Sabine) areas in Manitoba. 


\section{Vegetation Characteristics}

There were no significant differences in protein content of either Medicago lupulina $\left(F_{2,28}=0.74, P=0.50\right)$ or Poa pratensis $\left(F_{2.29}=1.57, P>0.20\right)$, vegetation height $\left(F_{2,51}=1.67, P>0.20\right)$, or forage biomass $\left(F_{2,51}\right.$ $=0.16, P>0.80)$ among the three squirrel density levels (Table 3). However, there was a slight decreasing trend in biomass of legumes, grasses, and total forage from low to high ground squirrel density. This trend likely reflects a decrease in available forage from low to high density. The high legume biomass in low-density areas relative to intermediate- and high-density areas was striking, although it still fell short of statistical significance $\left(F_{2,49}=2.09, P>0.10\right)$.

\section{Soil Characteristics}

Soil nitrate/nitrite content was significantly higher in low ground squirrel density areas than either intermediate- or high-density areas $\left(F_{2,40}=332.37, P<0.01\right.$; Table 4). Soil moisture was also significantly higher in low-density than high-density areas $\left(F_{2,52}=3.82, P<\right.$ 0.05 ; Table 4). However, this result must be interpreted cautiously, given that moisture samples were taken on only one day in a summer season with atypically high precipitation (Environment Canada reports $481.4 \mathrm{~mm}$ of rain for 2010 in this region, with $37.1 \%$ of that accumulating between June and July, whereas mean annual precipitation is $514.5 \mathrm{~mm}$ with $75.6 \%$ of that falling as snow between October and April). There were no significant differences in soil ammonia or bulk density among density levels (Table 4).

TABLE 3. Mean dry biomass per quadrat ( \pm standard deviation) for legumes, grasses, forage, and litter, plant biomass density, plant height, and crude protein content for Medicago lupulina and Poa pratensis at three Richardson's Ground Squirrel (Urocitellus richardsonii Sabine) density levels in an aspen parkland pasture in Manitoba.

\begin{tabular}{|c|c|c|c|c|}
\hline & \multicolumn{3}{|c|}{ Squirrel density } & \multirow[b]{2}{*}{$n$} \\
\hline & Low & Intermediate & High & \\
\hline \multicolumn{5}{|l|}{ Legumes } \\
\hline Total biomass, $\mathrm{g} / \mathrm{m}^{*}$ & $15.0 \pm 3.6$ & $15.8 \pm 2.4$ & $6.8 \pm 2.1$ & 18 \\
\hline Proportion & $0.2 \pm 0.1$ & $0.2 \pm 0.0$ & $0.1 \pm 0.0$ & 18 \\
\hline \multicolumn{5}{|l|}{ Grasses } \\
\hline Total biomass, $\mathrm{g} / \mathrm{m} \dagger$ & $53.7 \pm 5.0$ & $50.0 \pm 4.5$ & $47.8 \pm 5.1$ & 18 \\
\hline Proportion & $0.8 \pm 0.1$ & $0.8 \pm 0.0$ & $0.9 \pm 0.0$ & 18 \\
\hline Total forage biomass, $\mathrm{g} / \mathrm{m} \ddagger$ & $68.8 \pm 4.2$ & $65.8 \pm 5.0$ & $54.7 \pm 4.7$ & 18 \\
\hline Litter, $g / \mathrm{m}$ & $37.5 \pm 4.1$ & $32.8 \pm 4.2$ & $35.4 \pm 3.8$ & 18 \\
\hline Plant biomass density, $\mathrm{g} / \mathrm{m}^{3}$ & $392.3 \pm 50.6$ & $459.1 \pm 100.0$ & $292.8 \pm 45.0$ & 18 \\
\hline Plant height, $\mathrm{cm}$ & $5.4 \pm 0.4$ & $6.7 \pm 1.0$ & $5.0 \pm 0.3$ & 18 \\
\hline \multicolumn{5}{|l|}{ Crude protein } \\
\hline Medicago lupulina, $\mu \mathrm{g} / \mathrm{g}$ & $30.6 \pm 10.3$ & $25.8 \pm 4.4$ & $42.4 \pm 11.1$ & 8 \\
\hline Poa pratensis, $\mu \mathrm{g} / \mathrm{g}$ & $19.6 \pm 1.3$ & $22.9 \pm 1.4$ & $19.4 \pm 1.7$ & 8 \\
\hline
\end{tabular}

*Includes Medicago lupulina, Trifolium pratense, and Lotus corniculatus.

$\dagger$ Includes Phleum pratense, Elymus repens, Poa pratensis, and Bromus inermis.

Includes all grass and legume species in addition to trace amounts of forb species not reported individually.

TABLE 4. Soil characteristics (mean \pm standard deviation) in plots with low, intermediate, and high densities of Richardson's Ground Squirrel (Urocitellus richardsonii Sabine) in an aspen parkland pasture in Manitoba.

\begin{tabular}{lccc}
\hline \hline & \multicolumn{3}{c}{ Squirrel density } \\
\cline { 2 - 4 } Soil characteristic & Low & Intermediate & High \\
\hline Moisture, $\mathrm{mV}^{*}$ & $714.28 \pm 18.58 \mathrm{a}$ & $678.83 \pm 22.41 \mathrm{ab}$ & $634.18 \pm 19.69 \mathrm{~b}$ \\
Bulk density, $\mathrm{g} / \mathrm{cm}^{3}$ & $0.97 \pm 0.04$ & $0.92 \pm 0.04$ & $0.94 \pm 0.03$ \\
Nitrate/nitrite content $\mathrm{mg} / \mathrm{kg}^{*}$ & $14.57 \pm 4.58 \mathrm{a}$ & $5.83 \pm 0.78 \mathrm{~b}$ & $5.96 \pm 1.23 \mathrm{~b}$ \\
Ammonia content, $\mathrm{mg} / \mathrm{kg}$ & $4.74 \pm 0.24$ & $5.62 \pm 0.87$ & $4.14 \pm 0.21$ \\
\hline \hline
\end{tabular}

*Different letters indicate significant differences between density levels $(P<0.05)$.

\section{Discussion}

Our study set out to assess changes in forage quality caused by Richardson's Ground Squirrel foraging activities on a pasture in Manitoba's aspen parkland region. The positive correlation between active burrow counts and number of above ground individuals in high-, intermediate-, and low-density areas suggests that the contrast among those areas in terms of squirrel foraging activity is robust. It is unlikely that differences among density levels were the result of underlying spatial heterogeneity in microhabitat, given the absence of any obvious environmental gradients delineating those areas or any difference in topography or soil type, density, moisture, or ammonia levels among them. In fact, although the abundance of inactive burrows in the lowdensity areas implies that lagging effects of high-inten- 
sity ground squirrel foraging before local extirpation may be at work, it also indicates that these low-density areas were suitable for occupancy by ground squirrels and, thus, were qualitatively equivalent to the current high-density areas before squirrels were removed in 2009.

\section{Forage Quality Changes and Implications for Cattle}

In our study, Richardson's Ground Squirrels did not have a significant impact on crude protein content or available forage (in terms of biomass and height), which is inconsistent with our hypotheses. However, increased ground squirrel density was associated with significant reductions in soil nitrate content and plant community composition, which shifted away from Bromus inermis and Trifolium pratense with concomitant increases in Elymus repens and Medicago lupulina cover. Crude protein content of legume hays containing $T$. pratense has been shown to exceed that of M. lupulina hays (Kiraz 2011). The increase in M. lupulina cover relative to $T$. pratense in our pasture may affect forage nutritional quality, although our study detected no differences in protein content among ground squirrel density levels on a per-species basis. For example, an increase in T. pratense over M. lupulina in high-density ground squirrel areas may increase pasture-wide crude protein available to cattle. Alternatively, the increase in the ratio of Elymus repens to Bromus inermis associated with increasing squirrel density may decrease protein availability for cattle, as fresh $B$. inermis forage exceeds $E$. repens in crude protein content in all but spring pasture (McCartney 1993; National Research Council 1996a). Energy acquired from feed cannot be used by beef cattle for growth and maintenance of tissues if it is not balanced with respect to amino acid supply (Kerley 2012). Therefore, the promotion of the availability of high-protein forages by Richardson's Ground Squirrels may contribute to improved cattle weight gain in the region, as long as forage biomass is not also significantly reduced.

Our results conflict with the drastic changes in forage quality often attributed to ground-dwelling rodents. For example, in a study of effects of the Black-tailed Prairie Dog (Cynomys ludovicianus) on a plant community in Texas, standing crop off-colony was more than three times that on-colony (Weltzin et al. 1997). Howard et al. (1959) reported that removal of California Ground Squirrels (Otospermophilus beecheyi) from California pasture for 2 years significantly increased available plant biomass. However, studies documenting these dramatic effects were performed between the mixedgrass prairie of the central Great Plains region (Coppock et al. 1983) and northern California (Howard et al. 1959). Both biotic and abiotic conditions change with altitude and region, and this may account for the discrepancy between results obtained in the current and previous studies.

Further, because our study focused on the effects of Richardson's Ground Squirrels on a cattle-grazed pas- ture, we did not include any off-colony plots, which may prove integral to the detection of significant impacts of ground-dwelling rodents on pastureland vegetation, as areas without grazing by squirrels would preclude any influence of past foraging effects. For example, Fahnestock and Detling (2002) detected no difference in the number of forb species among prairie dog exclosed and non-exclosed plots on colonies, but did note a significant difference in the number of forb species among on-colony and off-colony plots.

Alternatively, our failure to detect a significant difference in forage protein content and available biomass could result from our relatively small sample size and the extensive variability among samples. Future studies require more intensive sampling and adequate replication to fully assess the influence of ground squirrel density on the availability and protein content of forage.

\section{Ground Squirrel Foraging and Species Diversity}

Grime (1973) suggested that in disturbed environments, diversity is greatest at an intermediate and optimal disturbance level where plants adopting stresstolerator and competitor strategies are equally able to cope. Intermediate levels of foraging pressure have also been suggested to optimize plant productivity in terms of both growth and nutrient content (McNaughton 1979). In our study, the highest diversity (species richness and evenness) was observed at intermediate squirrel density, consistent with the intermediate disturbance hypothesis and confirming our hypothesis that moderate foraging activity by Richardson's Ground Squirrels at our site may enhance plant species diversity. It remains unclear, however, whether the highest measured diversity in our study represents the maximum species diversity (in terms of richness and evenness) for this pasture, or indeed for other pastures in the region. Future studies should replicate measurements across both time and space to capture a larger range of ground squirrel densities.

Changes in forage quality associated with the reduction of Bromus inermis and Trifolium pratense in highdensity areas may be offset by increases in pasture diversity. As noted above, plant species diversity was highest where squirrel density was intermediate. This trend, at least in part, is attributable to the reduction in $B$. inermis with increasing squirrel density. Despite its original use as a rangeland forage species (McCartney 1993), B. inermis is an invasive grass in southwestern Manitoba and has been shown to decrease plant diversity and the abundance of native species in mixedgrass and fescue prairies by up to $70 \%$ (Otfinowski et al. 2007). The processes by which Richardson's Ground Squirrels control this species are unclear, but could include selective removal of plant tissue through herbivory or clipping, facilitation of competitors, such as Elymus repens, or by damage to tissues through soil disturbance. 


\section{Changes in Legume Abundance and Implications for} Cattle

In addition to altering species composition, ground squirrel density appears to affect relative grass-legume abundance, contributing to spatial heterogeneity in soil inorganic nitrogen concentrations. Grasses and legumes are expected to coexist at equilibrium at various abundances depending on soil nitrate. When soil nitrate is low, nitrogen fixers (legumes) have an advantage and, therefore, should have a higher equilibrium abundance; when soil nitrate is high, uptake by non-fixers (grasses) should be more efficient and their equilibrium abundance should be greater (Thornley et al. 1995). Consequently, soil nitrate would be expected to be highest where the density of animals and, thus, the intensity of urination (nitrogen input) is highest; by the same logic, these areas should also contain the lowest abundance of nitrogen-fixers.

In the current study, the highest soil nitrate levels were detected in low ground squirrel density areas, which is inconsistent with our hypothesis. Those lowdensity areas also had the highest legume abundance, which, on the surface, appears paradoxical. Entz et al. (2001) report, however, that soil nitrate values greater than $8 \mathrm{mg} / \mathrm{kg}$ in the southern Manitoba region are high. Thus, the average nitrate values between 5.83 and $14.57 \mathrm{mg} / \mathrm{kg}$ observed on our pasture are relatively high for the region, and it is unclear whether the difference between high- and low-density areas (although significant) captures enough variation in nitrate content to influence the competitive interaction between legumes and grasses.

Lower soil nitrogen in high-density areas may be caused by reduced input of organic matter into soil surrounding the intensely grazed plants. Derner et al. (1997) found that although total nitrogen is generally higher in the vicinity of caespitose grasses in mid- and tall-grass prairie, the trend is reversed on intensely grazed sites because grazing-adapted grasses produce less biomass and, thus, do not contribute as much organic matter to the surrounding soil. Finally, it is unclear whether the decrease in legume abundance in high ground squirrel density areas equates with a reduction in the number of individual plants, the size of plants, or the proportion of resources allocated to shoot-versusroot growth, all of which would produce measurable decreases in legume shoot biomass and cover.

Cattle may benefit directly from the reduction in the ratio of legumes to grasses available in ground squirrel rich areas. Although legumes are important constituents of cattle forage owing to their high crude protein, pectin, and mineral content relative to grasses, the overconsumption of legumes by cattle results in nitrogen wastage by denitrification in legume-dominated pastures (Laidlaw and Teuber 2001). This may further reduce nitrate availability and compound shifts in relative grass-legume abundance. Moreover, cattle are prone to bloat when grazing intensively on legumes, including
Trifolium pratense and Lotus corniculatus. Maintenance of a grass-legume sward reduces the incidence of bloat (Laidlaw and Teuber 2001) and has been emphasized repeatedly in the literature as a means of producing optimal grazing conditions for cattle (e.g., National Research Council 1996b; Harris et al. 1998).

Although Richardson's Ground Squirrels modified plant species composition and nutrient cycling on the pasture in our study, their effects on forage availability and nutrient content are not as clear. Where other research has explored the effects of ground-dwelling squirrels on rangeland forage (in South Dakota, Wyoming, California), the ability to detect dramatic changes in forage quality may be explained by larger sample sizes and replication across space and time, as well as the inclusion of off-colony sample plots. That caveat aside, within the limits of the present study, ground squirrel density increased species diversity and appears to have altered forage quality for the grazing cattle. Although the fact that we sampled plots of differing ground squirrel densities within a single pasture precludes generalizing our findings to other pastures in the aspen parkland region, our findings clearly suggest the need for an expanded research agenda, wherein the conditions under which ground squirrels alter the quality of pastureland are identified and the mechanisms underlying both the negative and positive effects of ground squirrel-cattle co-foraging are further elucidated.

\section{Acknowledgements}

We thank the Johnston family of Westbourne, Manitoba, for the use of their pasture and Dr. John Markham and Dr. Sylvie Renault for consultation and use of laboratory space, equipment, and chemicals throughout the study. Rob Ellis performed the soil nitrate analysis. Dr. Norm Kenkel performed the multivariate statistical analyses and aided in interpretation of results. Peter Tarleton assisted with collection of field data. We thank two anonymous referees and Canadian Field-Naturalist editors for their valuable comments, which improved the quality of our manuscript.

\section{Literature Cited}

Batzli, G. O., and S. T. Sobaski. 1980. Distribution, abundance, and foraging patterns of ground squirrels near Atkasook, Alaska. Arctic and Alpine Research. 12: 501-510.

Bradford, M. M. 1976. A rapid and sensitive method for the quantitation of microgram quantities of protein utilizing the principle of protein-dye binding. Analytical Biochemistry 72: 248-254.

Brook, R. K., and N. C. Kenkel. 2002. A multivariate approach to vegetation mapping of Manitoba's Hudson Bay Lowlands. International Journal of Remote Sensing 23: 4761-4776.

Calder, A. 2003. Why shoot the gopher? Reading the politics of a prairie icon. American Review of Canadian Studies 33: 391-414.

Clesceri, L. S., A. E. Greenberg, and A. D. Eaton. 1998. Standard Methods for the Examination of Water and Wastewater. United Book Press, Baltimore, Maryland, USA. 
Coppock, D. L., J. E. Ellis, J. K. Detling, and M. I. Dyer. 1983. Plant-herbivore interactions in a North American mixed-grass prairie. II: Responses of bison to modification of vegetation by prairie dogs. Oecologia 56: 10-15.

Davis, L. S. 1984. Alarm calling in Richardson's ground squirrels (Spermophilus richardsonii). Zeitschrift für Tierpsychologie 66: 152-164.

Derner, J. D., D. D. Briske, and T. W. Boutton. 1997. Does grazing mediate soil carbon and nitrogen accumulation beneath $\mathrm{C}_{4}$, perennial grasses along an environmental gradient? Plant and Soil 191: 147-156.

Entz, M. H., W. J. Bullied, D. A. Forster, R. Gulden, and J. K. Vessey. 2001. Extraction of subsoil nitrogen by alfalfa, alfalfa-wheat, and perennial grass systems. Agronomy Journal 93: 495-503.

Fahnestock, J. T., and J. K. Detling. 2002. Bison-prairie dog-plant interactions in a North American mixed-grass prairie. Oecologia 132: 86-95.

Grime, J. P. 1973. Competitive exclusion in herbaceous vegetation. Nature 242: 344-347.

Harris, S. L., M. J. Auldist, D. A. Clark, and E. B. L. Jansen. 1998. Effects of white clover content in the diet on herbage intake, milk production and milk composition of New Zealand dairy cows housed indoors. Journal of Dairy Research 65: 389-400.

Houlbrooke, D. J., J. J. Drewry, R. M. Monaghan, R. J. Paton, L. C. Smith, and R. P. Littlejohn. 2009. Grazing strategies to protect soil physical properties and maximise pasture yield on a Couthland dairy farm. New Zealand Journal of Agriculture Research 52: 323-336.

Howard, W. E., K. A. Wagnon, and J. R. Bentley. 1959. Competition between ground squirrels and cattle for range forage. Journal of Range Management 12: 110-115.

Jameson, W. C. 1973. On the eradication of the prairie dog a point of view. Bios 44: 129-135.

Johnson-Nistler, C. M., J. E. Knight, and S. D. Cash. 2005. Considerations related to Richardson's Ground Squirrel (Spermophilus richardsonii) control in Montana. Agronomy Journal 97: 1460-1464.

Jones, C. G., J. D. Hare, and S. J. Compton. 1989. Measuring plant protein with the Bradford assay. 1. Evaluation and standard method. Journal of Chemical Ecology 15: 979992.

Kerley, M. S. 2012. Nutrition and feed efficiency in beef cattle. Pages 75-92 in Feed Efficiency in the Beef Industry. Edited by R. A. Hill. Wiley-Blackwell, Somerset, New Jersey, USA.

Kiraz, A. B. 2011. Determination of relative feed value of some legume hays harvested at flowering stage. Asian Journal of Animal and Veterinary Advances 6: 525-530.

Kvålseth, T. O. 1991. Note on biological diversity, evenness, and homogeneity measures. Oikos 62: 123-127.

Laidlaw, A. S., and N. Teuber. 2001. Temperate forage grasslegume mixtures: advances and perspectives. Pages 85-92 in Proceedings of the 19th International Grassland Congress, São Pedro, São Paulo, Brazil. International Grassland Congress, Québec, Quebec, Canada.

Laundre, J. W. 1993. Effects of small mammal burrows on water infiltration in a cool desert environment. Oecologia 94: 43-48.

Martin, P., and P. Bateson. 1986. Measuring Behaviour: An Introductory Guide. Cambridge University Press, New York, New York, USA.

McCartney, D. H. 1993. History of grazing research in the aspen parkland. Canadian Journal of Animal Science 73: 749-763.
McNaughton, S. J. 1979. Grazing as an optimization process: grass-ungulate relationships in the Serengeti. American Naturalist 113: 691-703.

Michener, G. R. 1981. Ontogeny of spatial relationships and social behaviour in juvenile Richardson's ground squirrels. Canadian Journal of Zoology 59: 1666-1676.

Mudge, J. F., L. F. Baker, C. B. Edge, and J. E. Houlahan. 2012. Setting an optimal $\alpha$ that minimizes errors in null hypothesis significance tests. PLoS ONE 7: e32734.

National Research Council, Subcommittee on Beef Cattle Nutrition. 1996a. Composition of selected feeds. Pages 133-148 in Nutrient Requirements of Beef Cattle. National Academy Press, Washington, D.C., USA.

National Research Council, Subcommittee on Beef Cattle Nutrition. 1996b. Tables of nutrient requirements. Pages 102-112 in Nutrient Requirements of Beef Cattle. National Academy Press, Washington, D.C., USA.

Otfinowski, R., N. C. Kenkel, and P. M. Catling. 2007. The biology of Canadian weeds. 134. Bromus inermis Leyss. Canadian Journal of Plant Science 87: 183-198.

Poulin, R. G., L. D. Todd, K. M. Dohms, R. M. Brigham, and T. I. Wellicome. 2005. Factors associated with nestand roost-burrow selection by burrowing owls (Athene cunicularia) on the Canadian prairies. Canadian Journal of Zoology 83: 1373-1380.

Proulx, G., K. MacKenzie, and N. MacKenzie. 2012. Distribution and relative abundance of Richardson's Ground Squirrels, Urocitellus richardsonii, according to soil zones and vegetation height in Saskatchewan during a drought period. Canadian Field-Naturalist 126: 103-110.

Simpson, E. H. 1949. Measurement of diversity. Nature 163: 688.

Stewart, K. E. J., N. A. D. Bourn, and J. A. Thomas. 2001. An evaluation of three quick methods commonly used to assess sward height in ecology. Journal of Applied Ecology 38: 1148-1154

Thornley, J. H. M., J. Bergelson, and A. J. Parsons. 1995. Complex dynamics in a carbon-nitrogen model of a grasslegume pasture. Annals of Botany 75: 79-94.

Wallace, J. D., J. C. Free, and A. H. Denham. 1972. Seasonal changes in herbage and cattle diets on sandhill grassland. Journal of Range Management 25: 100-104.

Weltzin, J. F., S. L. Dowhower, and R. K. Heitschmidt. 1997. Prairie dog effects on plant community structure in southern mixed-grass prairie. Southwest Naturalist 42: 251258.

Whisson, D. A., S. B. Orloff, and D. L. Lancaster. 1999. Alfalfa yield loss from Belding's ground squirrels in northern California. Wildlife Society Bulletin 27: 178-183.

Whittaker, R. H. 1972. Evolution and measurement of species diversity. Taxon 21: 213-251.

Winter, S. L., J. F. Cully, and J. S. Pontius. 2002. Vegetation of prairie dog colonies and non-colonized short-grass prairie. Journal of Range Management 55: 502-508.

Wywialowski, A. P. 1994. Agricultural producers' perceptions of wildlife-caused losses. Wildlife Society Bulletin 22: 370382.

Zhao, L., J. He, X. Wang, and L. Zhang. 2008. Nitric oxide protects against polyethylene glycol-induced oxidative damage in two ecotypes of reed suspension cultures. Journal of Plant Physiology 165: 182-191.

Received 4 September 2013

Accepted 2 November 2015 